\title{
RESPIRATORY SYNCYTIAL VIRUS INFECTION INDUCES EXPRESSION OF INDUCIBLE NITRIC OXIDE SYNTHASE, CD3, AND CD8 IN NATURALLY OCCURRING PNEUMONIA IN LAMBS
}

\author{
Turan YAMAN $^{1 *}$, Ceyhun AYDEMİR ${ }^{2}$ \\ ${ }^{1}$ Department of Pathology, Faculty of Veterinary Medicine, Van Yuzuncu Yil University, Van, Turkey; \\ ${ }^{2}$ Van Training and Research Hospital, Saglik Bilimleri University, Van, Turkey
}

(Received 04 March 2020, Accepted 10 March 2021)

\begin{abstract}
Respiratory syncytial virus (RSV) is an RNA virus that belongs to the Pneumovirus genus of the Paramyxoviridae family. The aim of this study was to evaluate the expressions of inducible nitric oxide synthetase (iNOS), CD3 (pan T cells), and CD8 (cytotoxic T cells) in lamb lungs naturally infected with RSV using immunohistochemistry (IHC). For this purpose, 100 pneumonic and 10 control lung tissue samples were taken from lambs slaughtered in the slaughterhouse after macroscopic examination. The streptavidinperoxidase method (ABC) was used for IHC staining, and it revealed RSV positivity in 18 of 100 examined lungs with pneumonia (18\%). These positive cases were then immunostained for iNOS, $\mathrm{CD} 3$, and $\mathrm{CD} 8$, and compared to controls. In all these cases, an increase in iNOS expression $(100 \%)$ was detected, the higher number of $\mathrm{CD}^{+} \mathrm{T}$ lymphocytes was detected in $14(78 \%)$ cases while $\mathrm{CD}^{+} \mathrm{T}$ lymphocytes were detected in five $(28 \%)$ cases, only. Given the increase of iNOS immunoexpression in all RSVpositive cases and increase in the number of $\mathrm{CD}^{+} \mathrm{T}$ lymphocytes in most cases, it was concluded that iNOS and $\mathrm{CD}^{+} \mathrm{T}$ lymphocytes play an important role in the immune response in lamb pneumonia with naturally occurring RSV infection. With this study, the role of the mentioned markers was evaluated for the first time in lambs naturally infected with RSV.
\end{abstract}

Key words: CD3, CD8, immunohistochemistry, iNOS, lamb, RSV

\section{INTRODUCTION}

Respiratory diseases in sheep cause major economic losses in the sheep industry in many countries [1]. Respiratory syncytial virus (RSV), a pneumovirus of the Paramyxoviridae family, is an important respiratory pathogen in humans [2], and bovine, ovine, and caprine RSV types have been identified in ruminants [3,4]. Serological research has revealed that RSV is common in sheep in Turkey $[1,5]$.

*Corresponding author: e-mail: turanyaman@yyu.edu.tr 
It has been emphasized that an adaptive immune response should be developed for control and clearance of RSV infections [6]. Researchers have stated that there may be differences in the functionality of the cells collected at the site of infection, and these differences may play a key role in RSV infection [7]. It has been experimentally demonstrated that macrophages, neutrophils, and helper and cytotoxic T lymphocyte cells are involved in the immune response in newborn lambs infected with the human RSV strain [7]. Bovine RSV-infected calves show increased CD8 T lymphocyte infiltration in the lungs, trachea, and nasopharynx [8]. In mice and humans, CD8 T cells have been reported to mediate the elimination of primary RSV infection [9].

CD3 $\mathrm{T}$ lymphocytes, which play a role in the formation of the cellular and humoral immune responses [10], are critical for the adaptive immune response to most viral infections [11]. CD3 T cells have been reported to be important for understanding the pathogenesis of RSV. It has been emphasized that the role of this immune response component should be considered in vaccine approaches to prevent RSV infections [11].

Nitric oxide (NO) is a gaseous inorganic radical produced endogenously in several cells and tissues. NO is involved in many important physiological functions, including blood vessel relaxation, inhibition of platelet aggregation [12], regulation of vascular tone, leukocyte adhesion, synaptic transmission, and cytostatic/cytotoxic actions of macrophages [13]. Experimental findings suggest that NO may play a role in immunological host defense mechanisms against pathogens and may be involved in signaling between macrophages and $\mathrm{T}$ cells $[14,15]$. In addition, NO is an antiviral effector of the immune system [16,17] and can inhibit the proliferation of various viruses $[15,18,19]$. It is produced from L-arginine via three different inducible NO synthases [20], namely, neuronal nitric oxide synthase (nNOS), inducible nitric oxide synthase (iNOS), and endothelial nitric oxide synthase (eNOS) [21].

Immunohistochemistry (IHC) staining is a safe method that facilitates the permanent and clear presentation of antigen components [22], and it is frequently used in the diagnostic evaluation of RSV antigens in formalin-fixed tissues, including viral antigens $[4,23]$. In cattle, detailed immunoperoxidase studies on RSV have been reported [24, 25]. However, there are only a few studies showing the presence of RSV in naturally infected goats [4,26] and sheep [22] by the IHC method. The aim of this study, was to evaluate the iNOS, CD3, and CD8 immune expression in RSV-positive naturally infected lamb pneumonia using the IHC method.

\section{MATERIAL AND METHODS}

An abattoir survey for prevalence of pneumonia in lambs was carried out on the lungs of approximately 2100 lambs brought to the abattoir for slaughtering, which were predominantly male, originating from dairy and beef herds of Van, Turkey. The gross appearance of lesions was recorded and totally 100 (4,8\%) pneumonia-suspected and 
10 control lung tissues were sampled. Tissue samples were collected at four different seasonal quarters of the year (spring, summer, autumn, and winter). Thus, the effect of seasonal factors on the development of the disease was examined, avoiding evaluation of the RSV infection of a specific region or flock at a specific time.

\section{Histopathological examination}

Lung tissue samples were taken from sacrificed lambs fixed in 10\% neutral formalin and embedded in paraffin by routine methods. Sections $5 \mu \mathrm{m}$ in thickness were cut for histological examination. The histopathological findings were evaluated on hematoxylin-eosin (H\&E) stained tissue slides using a light microscope (E-400; Nikon, Japan) equipped with a DS-Ri2 video camera (DS-U3, Nikon, Japan). The histopathological findings were evaluated semi quantitatively according to the severity of the lesions as $(-)$ no lesion, $(+)$ mild, $(++)$ moderate and $(+++)$ severe.

\section{Immunohistochemical staining}

The streptavidin-peroxidase method $(A B C)$ was used to stain the sections. Slides were deparaffinised and rehydrated. After quenching endogenous peroxidase activity with $3 \% \mathrm{H} 2 \mathrm{O} 2(\mathrm{v} / \mathrm{v})$ for $20 \mathrm{~min}$, the slides were washed twice in $0.01 \mathrm{M}$ PBS for 5 min. Heat-induced antigen retrieval was performed with citrate buffer $(\mathrm{pH} 6.0)$ for 30 min at $95{ }^{\circ} \mathrm{C}$ using a water bath and by cooling for $20 \mathrm{~min}$. Before adding the primary antibodies, the slides were incubated with blocking serum (Histostain Plus Bulk Kit, Zymed, USA) for 15 min to block nonspecific binding. All samples were incubated with polyclonal sera raised against RSV at $4^{\circ} \mathrm{C}$ overnight in a humidified chamber. After incubation, the slides were washed four times in $0.01 \mathrm{M}$ PBS for $5 \mathrm{~min}$, incubated with biotinylated secondary antibody (Histostain Plus Bulk Kit, Zymed) for $20 \mathrm{~min}$ at room temperature $\left(20-25^{\circ} \mathrm{C}\right)$, then washed four times in $0.01 \mathrm{M}$ PBS for $5 \mathrm{~min}$. After incubation with the secondary antibody, the sections were incubated with streptavidin-peroxidase (HRP) conjugate (Histostain Plus Bulk Kit, Zymed) for $20 \mathrm{~min}$, then washed four times in $0.01 \mathrm{M}$ PBS for 5 min following enzymatic incubation. To visualize the reactions, the sections were incubated for 5-15 min with diaminobenzidine $(\mathrm{DAB})$. After the development of the DAB reaction, the sections were counterstained with Gill's haematoxylin. Then the sections were passed through alcohols and xylene and mounted directly with Entellan mounting medium. After RSV immunostaining, RSV positive samples were immunostained with antibodies for the detection of iNOS, CD3 and CD8 T cells following the same staining protocol as above. The slides incubated with PBS instead of primary antibodies served as negative controls to verify the immunostaining (Table 1).

Immunohistochemical findings were evaluated subjectively according to the intensity of staining in the tissue as $(-)$ negative, $(+)$ mild, $(++)$ moderate and $(+++)$ intense, using a light microscope (E-400; Nikon, Japan) equipped with a DS-Ri2 video camera (DS-U3, Nikon, Japan). 
Table 1. Antibody specificity, host, dilution rates and incubation times

\begin{tabular}{llccl}
\hline Antibody & Host & Dilution & Incubation & \multicolumn{1}{c}{ Source } \\
\hline RSV & Mouse & $1 / 100$ & Overnight & Thermo Fisher Sci-MA1-80661 \\
anti-iNOS & Rabbit & $1 / 100$ & Overnight & abcam-ab15323 \\
CD3 & Rabbit & $1 / 100$ & Overnight & Ventana-790-4341 \\
CD8 & Mouse & $1 / 100$ & Overnight & Novocastra-NCL-L-CD8-4B11 \\
\hline
\end{tabular}

\section{RESULTS}

\section{Macroscopic findings}

A total of 2100 lamb lungs were grossly examined, and pneumonia lesions consistent with RSV bronchointerstitial pneumonia were detected in 100 cases (4.8\%). Pneumonic lesions were usually localized in the cranial lobes, comprising entire lobes or had a lobular pattern. The affected areas were dark red or gray-white and consolidated. The interlobular septa were dilated and demarcation lines were evident between the pneumonic and unaffected areas (Figure 1).

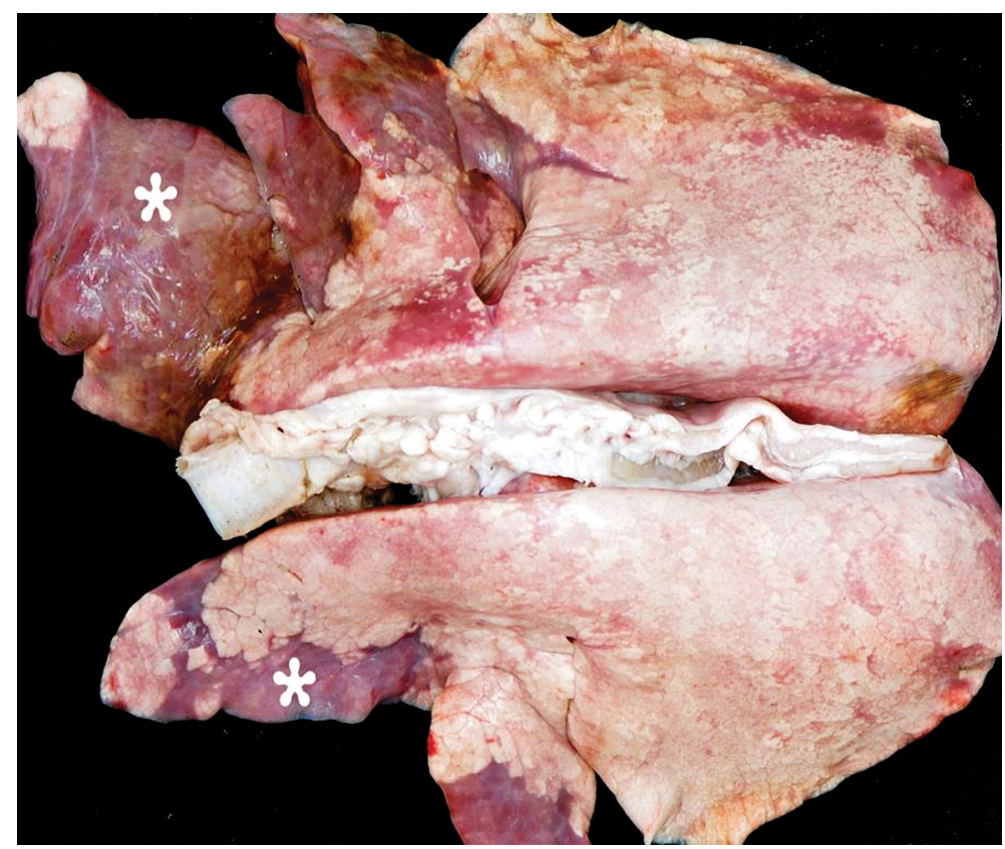

Figure 1. Macroscopic appearance of pneumonic lesions in a RSV-positive lung. Lobe distributed, red-colored consolidated areas (stars)

\section{Histopathological findings}

Histopatholoy of lung sections revealed predominantly bronchointerstitial $(n=37$; $37 \%)$, catarrhal-purulent $(n=17 ; 17 \%)$, or fibrinous $(n=25 ; 25 \%)$ pneumonia. Areas 
of interstitial or bronchointerstitial pneumonia showed changes characterized by expansion of the interalveolar walls as a result of mononuclear cell infiltration and congestion. The alveolar walls were lined with cuboidal type- 2 pneumocytes, which are intrinsic to viral pneumonia. Fibromuscular hyperplasia was observed in some alveolar walls. Syncytial cell formation was found in the bronchi, bronchioles, and alveolar lumina. The interlobular septa were dilated due to mononuclear cell infiltrations and edema. The exudate containing numerous neutrophils, cell debris, fibrin, erythrocytes, and macrophages was observed in the airways of sections with exudative lesions (Figure 2).

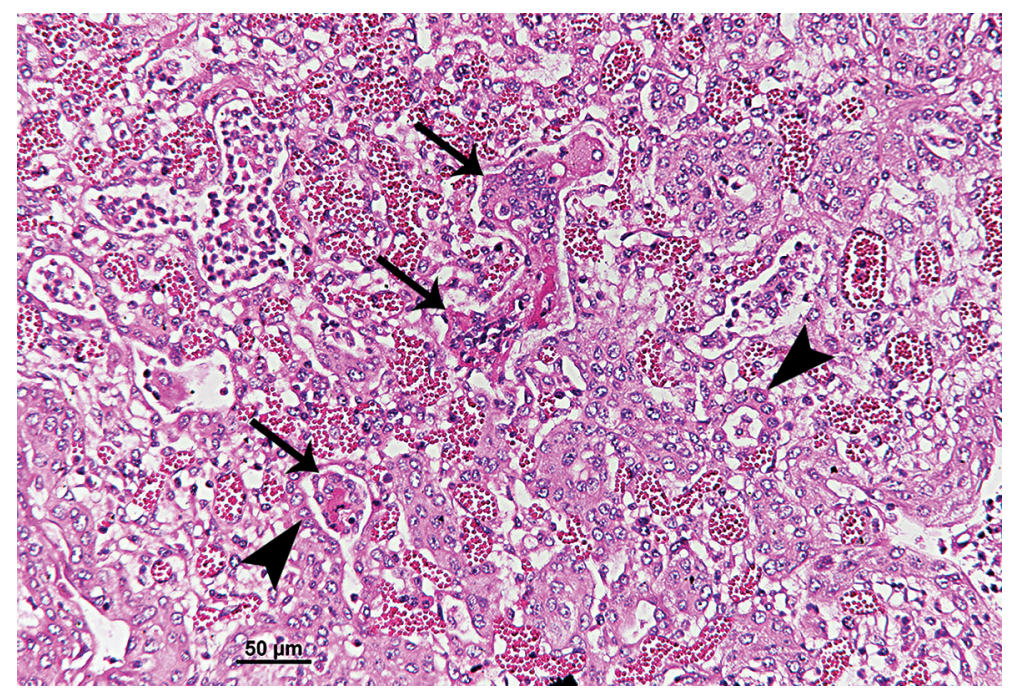

Figure 2. Lung, Lamb; Interstitial pneumonia. Syncytial cell formations (arrows) and proliferation of type II epithelial cells in the wall of alveoli (arrowheads); H\&E, Bar $=50 \mu \mathrm{m}$.

\section{Immunohistochemical findings}

The localisation and the frequency of immunoreactivity for RVS, iNOS, CD3 and CD8 within the lung parenchyma in $18 \mathrm{RSV}$ positive cases as confirmed by IHC, are presented in Table 3, and the staining intenstity is presented in Table 2.

Table 2. The intensity of IHC staining for respiratory syncytial virus (RSV), inducible nitric oxide synthetase (iNOS), CD3 (pan T cells), and CD8 in the lung of RSV positive cases

\begin{tabular}{ccccc}
\hline Case & $\begin{array}{c}\text { Immunoreactivity } \\
\text { with RSV and } \\
\text { the intensity of } \\
\text { the IHC signals* }\end{array}$ & $\begin{array}{c}\text { Immunoreactivity } \\
\text { with iNOS and } \\
\text { the intensity of } \\
\text { the IHC signals* }\end{array}$ & $\begin{array}{c}\text { Immunoreactivity } \\
\text { with CD3 and } \\
\text { the intensity of } \\
\text { the IHC signals* }\end{array}$ & $\begin{array}{c}\text { Immunoreactivity } \\
\text { with CD8 and } \\
\text { the intensity of } \\
\text { the IHC signals* }\end{array}$ \\
\hline 1 & + & ++ & +++ & - \\
\hline 2 & ++ & ++ & - & - \\
3 & + & + & - & - \\
4 & + & ++ & +++ & + \\
\hline
\end{tabular}


cont. Table 2 .

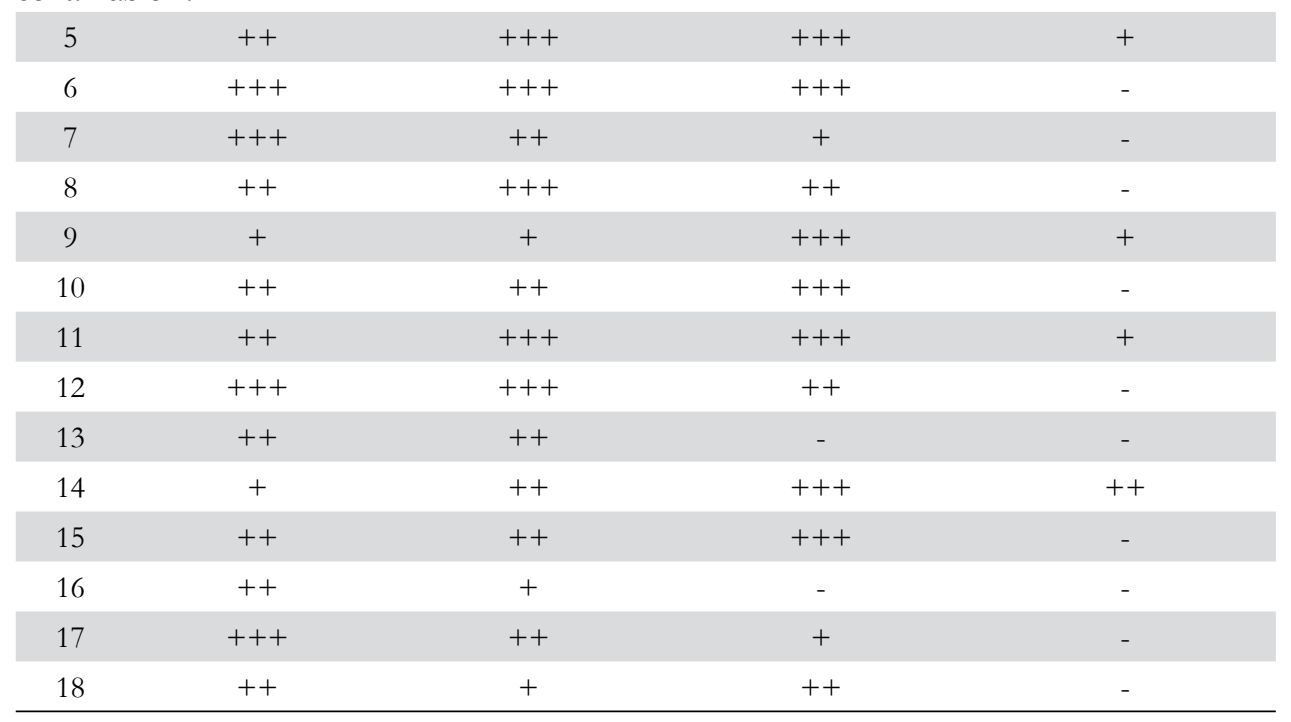

*Amount of antigen: - : negative; + : mild; ++ : moderate; +++ : intense

\section{Anti-RSV staining}

Immunohistochemical examinations revealed RSV positivity in 18 of 100 cases (18\%). Positive immunostaining was detected in the areas of bronchointerstitial pneumonia, with mostly mixed proliferative and exudative components. Immunoreactivity was observed in the cytoplasm of the bronchial and bronchiolar epithelial cells, in the propria and submucosa, in the connective tissue around the bronchial glands, and in the exudate and cellular debris found in the bronchial and bronchiolar lumina. In addition, immunopositivity was determined in the cytoplasm of inflammatory cells in the interlobular and interalveolar septa in the cytoplasm of macrophages, lymphocytes, and syncytial cells, and in the inflammatory exudate and cell debris in the alveolar lumina (Table 3, Figure 3). No reaction was detected in the peribronchial lymphatic follicles (BALT). Finally, there was no positive staining in the control group tissues.

Table 3. Distribution of IHC stained antigens in the lung tissue. Data show the number of cases where a particular localization of immunostaining was determined in RSV confirmed cases.

\begin{tabular}{ccccccccc}
\hline Antigen & $\begin{array}{c}\text { Alveolar } \\
\text { epithe- } \\
\text { lium }\end{array}$ & $\begin{array}{c}\text { Alveolar } \\
\text { lumen }\end{array}$ & $\begin{array}{c}\text { Bronchi, } \\
\text { bronchiole } \\
\text { epithelium }\end{array}$ & $\begin{array}{c}\text { Peribronch } \\
\text { and peri- } \\
\text { bronchiolar } \\
\text { area }\end{array}$ & $\begin{array}{c}\text { Bronchi, } \\
\text { bronchiole } \\
\text { lumen }\end{array}$ & $\begin{array}{c}\text { Peri- } \\
\text { bonchial } \\
\text { glands }\end{array}$ & $\begin{array}{c}\text { Inter- } \\
\text { stitium }\end{array}$ & $\begin{array}{c}\text { Vascular } \\
\text { endo- } \\
\text { thelium }\end{array}$ \\
\hline RSV & 10 & 12 & 15 & 17 & 8 & 6 & 14 & 3 \\
\hline iNOS & 7 & 9 & 8 & 18 & 3 & 0 & 9 & 18 \\
CD3 & 7 & 6 & 9 & 14 & 11 & 0 & 13 & 0 \\
\hline CD8 & 0 & 3 & 0 & 5 & 0 & 3 & 0 & 0 \\
\hline
\end{tabular}



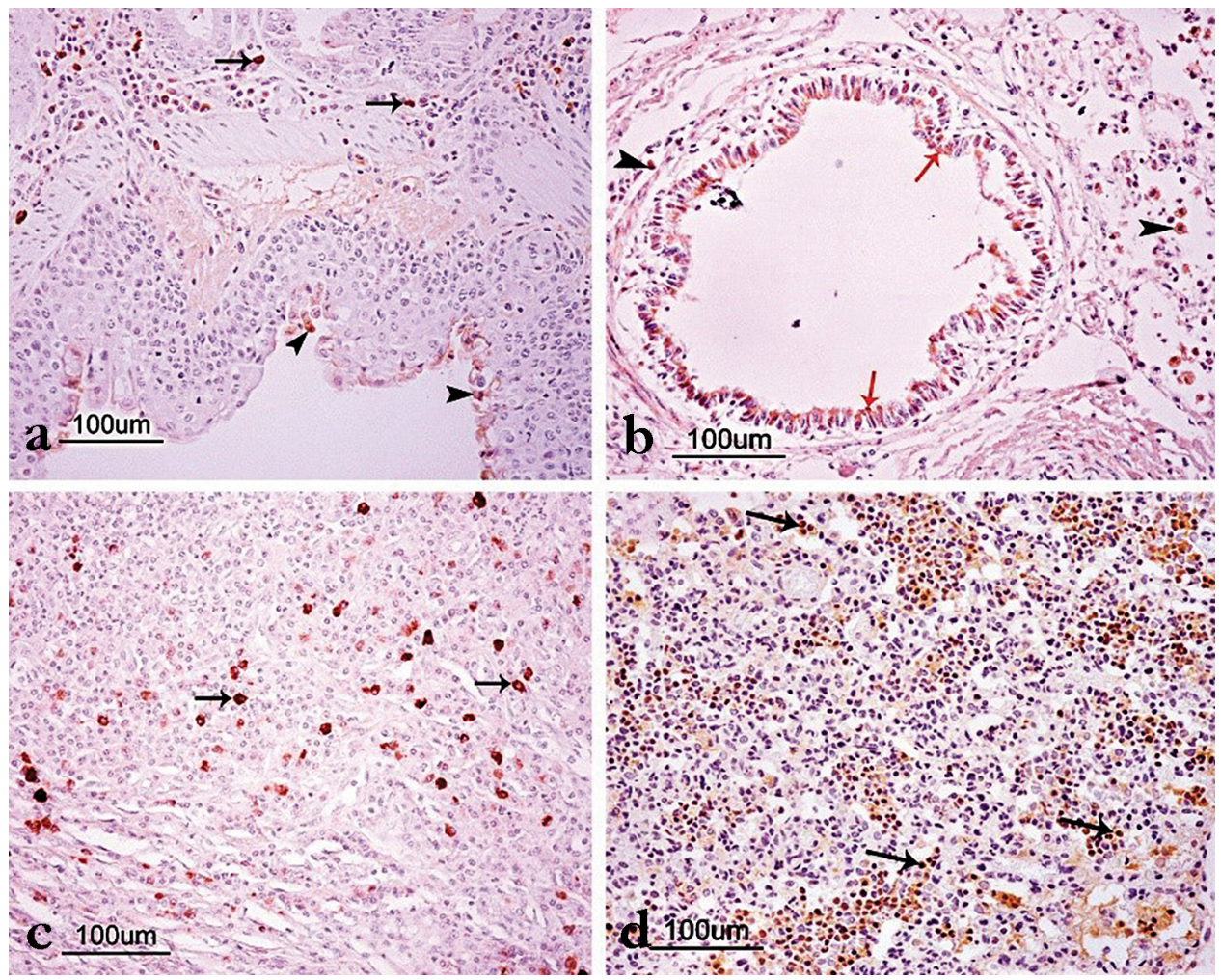

Figure 3. RSV immunostaining in lung tissue; A) RSV immuno-positivity in epithelium of bronchi (arrowheads) and inflammatory cells (arrows), Bar $=100 \mu \mathrm{m}$; B) RSV immunopositivity in epithelium of bronchioli (Red arrows) and inflammatory cells (arrowheads) in the alveolar lumina, Bar $=100 \mu \mathrm{m}$; C) RSV immunoreactivity in alveolar macrophages, $\mathrm{Ba}=$ $100 \mu \mathrm{m}$; D) RSV immunoreactivity in macrophages and exudate in the alveolar lumina (arrows). ABC-P, Bar $=100 \mu \mathrm{m}$.

\section{Anti-iNOS staining}

Expression of iNOS was seen in bronchial and bronchiolar epithelial cells in the lung sections of the control group. In addition, iNOS immunoreactivity was observed in the capillary endothelium but not in most arteries. Compared with the control group, the increase in iNOS immunoreactivity was observed in arterial endothelial cells in all the RSV-positive samples, especially in acute phase pneumonia cases. Reactivity in the capillary endothelium was especially increased in the peribronchial and peribronchiolar areas. However, immunoreactivity in the bronchial and bronchiolar epithelium did not increase compared to the control group of lambs. In addition, iNOS immunoreactivity was determined in the cytoplasm of the alveolar macrophages and inflammatory cells observed in the bronchial, bronchiolar, and alveolar lumina, and in the interstitium area. Immunoreactivity was not determined in neutrophils (Table 3, Figure 4). 


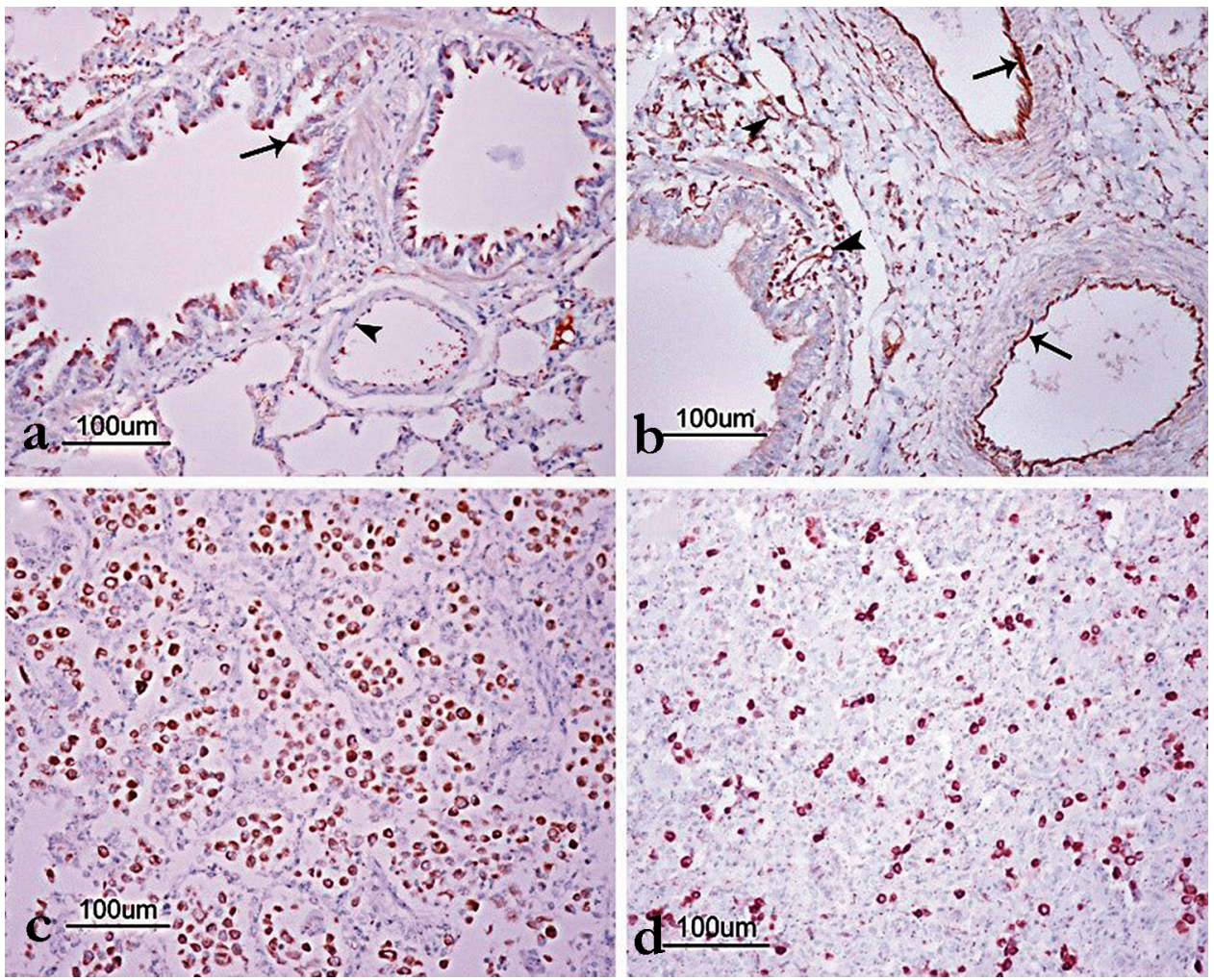

Figure 4. iNOS immunostaining in lung tissue; A) In the lambs of the control group, iNOS immunoreactivity was observed in the bronchiolar epithelial cells (arrows). Minimal reactivity was observed in the endothelium of the great artery (arrowhead), Bar $=100 \mu \mathrm{m}$; B) iNOS immunoreactivity in capillary and arterial endothelium in RSV positive lambs, Bar $=100 \mu \mathrm{m}$; C) iNOS immunoreactivity in alveolar macrophages in RSV positive lambs, Bar=100 $\mu \mathrm{m}$; D) iNOS immunoreactivity in inflammatory cells in alveolar lumen. ABC-P, Bar $=100 \mu \mathrm{m}$.

\section{Anti-CD3 staining}

$\mathrm{CD}^{+} \mathrm{T}$ cells were seen in peribronchial lymphatic follicles in the lung sections of the control group. Pneumonic samples showing similar CD3 immunoreactivity to that of the control group were considered negative. Fourteen (78\%) RSV-positive sections showed an increase in $\mathrm{CD} 3$ immunoreactive $\mathrm{CD}^{+} \mathrm{T}$ cells. In these sections, immunoreactive $\mathrm{CD}^{+} \mathrm{T}$ cells were detected in the bronchial lymph nodes, epithelial lining, propria, and submucosa of the bronchi and bronchioles, in all airway lumina, and in the intersitisyum around bronchial glands (Table 3, Figure 5). 

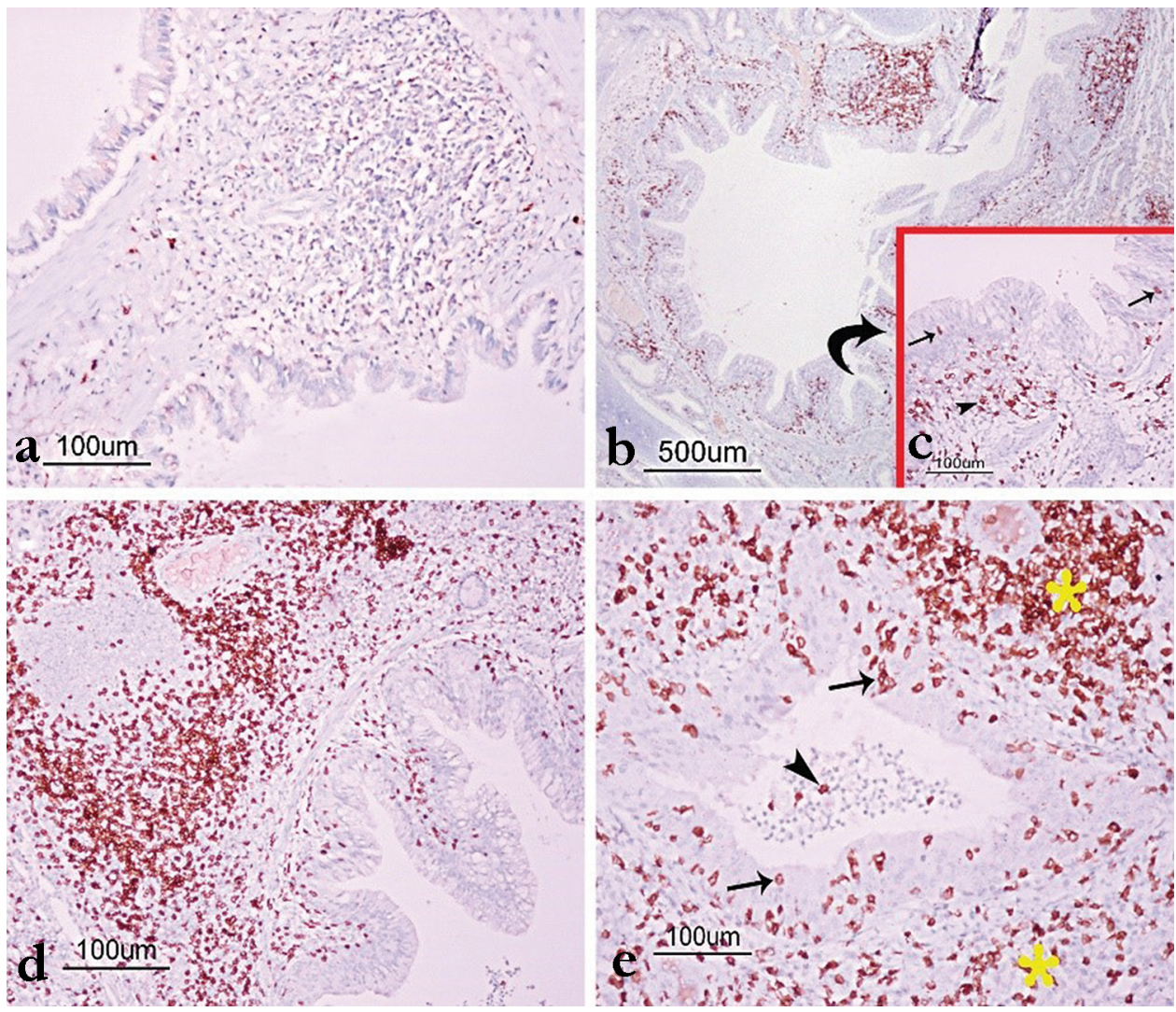

Figure 5. CD3 immunostaining in lung tissue; A) CD3+ T lymphocytes in a small number of cells in control lambs, Bar $=100 \mu \mathrm{m} ; \mathbf{B})$ Common CD3+ T lymphocytes in RSV positive lambs, Bar $=500 \mu \mathrm{m}$; C) CD3+ T lymphocytes in epithelial mucosa (arrows) and propria mucosa (arrowhead) of bronch, Bar $=100 \mu \mathrm{m}$; D) Common CD3+ T lymphocytes in propria mucosa and peribronchial area in RSV positive lambs. ABC-P, Bar=100 $\mu \mathrm{m}$; E: Common CD3+ T lymphocytes in the airway epithelium (arrows), lumina (arrowhead) and around the airway (stars) in RSV positive lamb. ABC-P, Bar $=100 \mu \mathrm{m}$.

\section{Anti-CD8 staining}

$\mathrm{CD}^{+} \mathrm{T}$ cells were not seen in the lung sections of the control group. In five $(28 \%)$ of the RSV-positive sections, CD8+ T cells were detected in the propria and submucosa of the bronchi and bronchioles, around the bronchial glands, and in the alveolar lumina (Table 3, Figure 6). 

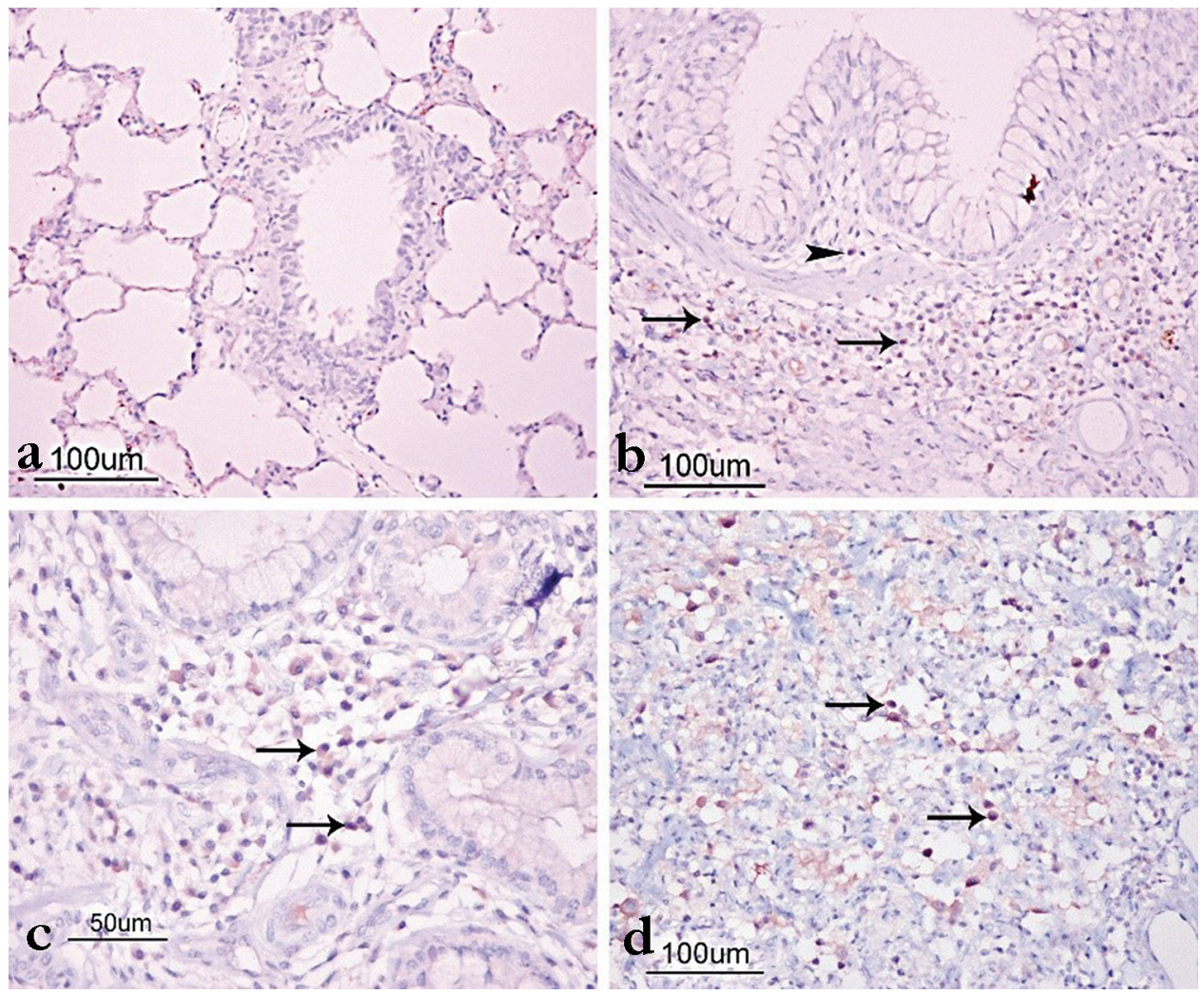

Figure 6. CD8 immunostaining in lung tissues; A) No CD8 immunoreactivity was observed in the control group lambs, $\mathrm{Bar}=100 \mu \mathrm{m}$; B) $\mathrm{CD} 8+\mathrm{T}$ lymphocytes in the propria mucosa (arrowhead) and submucosa (arrows) of RSV positive lambs, Bar=100 $\mu \mathrm{m}$; C) CD8+ T lymphocytes around the bronchial glands in RSV positive lambs (arrows), Bar=100 $\mu \mathrm{m}$; D) $\mathrm{CD} 8+\mathrm{T}$ lymphocytes in the alveolar lumina of RSV positive lambs (arrows). ABC-P, Bar = $100 \mu \mathrm{m}$.

\section{DISCUSSION}

Experimental RSV infection studies have been performed in many animal species [27-30]. There are studies describing the inflammatory cells in the respiratory tract in lambs [31,32], cattle [33,34], and experimental animals [35] that were intentionally infected with RSV. However, such studies have not been conducted in lambs naturally infected with RSV. Although experimental RSV infections allow for the presentation of clinical symptoms and lesions similar to those in native RSV infection, they do not fully reflect the naturally occurring disease [36]. This is because host factors, such as age, immune status, pulmonary defense mechanisms, presence of concurrent infections, and stress, can all determine the outcome of respiratory infections. Therefore, it is important to establish an experimental population by thoroughly evaluating all animals and eliminating many of these variables. In addition, it has been emphasized that 
differences in inoculation may occur in studies conducted with experimental RSV; the volume, titer, and pathogenicity can determine the effectiveness of the model [36]. In the present study, iNOS, CD3, and CD8 expression in inflammation in natural RSV infections.

Diagnosis of RSV is based on clinical findings, macroscopic examination, histopathological findings, and detection of viral antigens by IHC in affected tissue sections $[37,38]$. However, sheep have been reported to be especially susceptible to viruses, such as parainfluenza type-3 (PIV-3) and RSV [4,22]. The diagnosis of these viruses is macroscopically limited, and since most respiratory viruses are known to destroy ciliary activity and significantly reduce mucociliary clearance in the airway, they exhibit similar histopathological lung lesions [39,40]. Therefore, histological examination of hematoxylin and eosin (H\&E) sections is not sufficient for causal diagnosis, as the pathological changes in the lung are similar in PIV-3 and RSV infections [2]. In addition, RSV has been reported to be difficult to isolate because it is a slowly progressing virus in cell culture [1,24]. Moreover, in RSV, the virus is rarely isolated in natural infections in sheep [41], and a RSV strain may cause severe pathological changes in lambs' lungs without significant clinical symptoms [31]. For all these reasons, the IHC technique is frequently used as a fast and reliable method for the detection of RSV antigens in animals with respiratory diseases [22,25,42].

In our study, cytoplasmic RSV was detected in inflammatory cells in the interalveolar septa; exudate in the alveolar lumina, alveolar macrophages, peribronchial and peribronchiolar area, and bronchial and bronchiolar epithelial cells; and cellular debris in bronchial and bronchiolar lumina (see Table 3 and Figure 3), comparable to some previous studies $[4,6,22,25,26]$. Similar findings in RSV infection have been reported in experimentally infected BALB/c mice [43].

NO has been reported to have an antimicrobial activity against various pathogens due to its cytotoxic or cytostatic effects [15]. In vivo, NO has been shown to significantly contribute to the clearance of certain viruses [44,45]. Several viruses, including influenza [15], adenovirus [46], and rhinovirus [47] have been reported to increase NO production in the respiratory epithelium, both in vitro and in vivo. In RSV infection of respiratory epithelial cell culture, an increase in iNOS expression has been reported [48]. Stark et al. [49] reported that there was no significant change in the intensity or distribution of nNOS and eNOS after RSV infection compared with that in control mice. In contrast, iNOS staining increased significantly, especially in the respiratory epithelium and on days 4 and 7 after RSV infection. Thus, IHC analysis has revealed that the major NOS enzyme that changes during acute RSV infection is iNOS in the respiratory epithelium [49]. Western blot analysis showed an increase in iNOS isoforms on days 4 and 7 after RSV infection, and iNOS was the primary NOS isoform showing an increase after RSV infection. In addition, this increase has been shown to occur in respiratory epithelial cells [49]. In the present study, iNOS expression was increased in the capillary and arterial endothelium compared with controls, but no increase was found in the bronchial and bronchiolar epithelium (see Table 3 and Figure 4). 
Infection of respiratory epithelial cells with RSV resulted in the expression of certain pro-inflammatory proteins, including cytokines and chemokines (tumor necrosis factor $[\mathrm{TNF}]-\alpha$, interleukin [IL]-1 $\alpha, \mathrm{IL}-1 \beta, \mathrm{IL}-6, \mathrm{IL}-8,[49,50])$, receptor proteins $[52,53]$, and other important cell signaling molecules, including NO. Expression of iNOS has been identified in macrophages, neutrophils, endothelial and smooth muscle cells, and the respiratory epithelium, and it has been reported to be transcriptionally regulated by a series of pro-inflammatory cytokines, such as TNF- $\alpha$, interferon (IFN)- $\gamma$, IL-1 $\beta$, and nuclear factor $(\mathrm{NF})-x \mathrm{~B}[54,55]$. Furthermore, $\mathrm{NO}$ is a key mediator in the interaction of multiple cell types in respiratory inflammation and facilitates the migration of inflammatory cells into the airways [56]. Decreased numbers of macrophages, lymphocytes, and neutrophils have been reported after iNOS inhibition. Thus, the greatest effect of NO suppression is the reduction of inflammatory cells [49]. In our study, intense expression of iNOS in inflammatory cells and the vascular endothelium clearly revealed the role of iNOS in natural RSV infection. It was observed that iNOS immunoexpression was especially formed in lymphocytes and alveolar macrophages, whereas immunoexpression was not seen in neutrophils (Table 3). Choi et al. [57] reported that the major cell types expressing iNOS in the inflammation zone of tuberculosis granulomas are macrophages and multinucleated giant cells, but as expected, there was no iNOS expression in lymphocytes [57]. Therefore, it can be understood that the cell types in which iNOS is expressed may vary depending on the cause of the infection.

The role of NO in acute lung injury is controversial and has been shown to play beneficial and harmful roles in various lung diseases, such as asthma, chronic obstructive pulmonary disease, cystic fibrosis, and acute lung injury [58,59]. NO activity in the lungs has been reported to be a double-edged sword: NO production contributes to both airway inflammatory changes and respiratory dysfunction, in addition to increasing RSV clearance. It has been reported that RSV-induced NO production is involved in complex host responses and may mediate important aspects of the disease [49].

T lymphocytes are the primary cellular immune responses of RSV infection [7]. Immunohistochemically, the presence of CD3 T cells was detected in RSV pneumonia primarily in the area between pulmonary arterioles and small distal airways at high density and occasionally in the infected airway epithelium. These cells were also present in the alveolar interstitium. Furthermore, CD3 $+\mathrm{T}$ lymphocytes have been reported to be an important component of submuscular inflammatory infiltration around small bronchioles [11]. In our study, the presence of CD3+ T lymphocytes was determined in similar areas. In addition, these cells were found to constitute most of the inflammatory cells (see Table 3 and Figure 5).

Cytotoxic CD8 T cells play a critical role in the control and clearance of RSV infection [60]. In lung lavage fluid from BRSV-infected lambs, the presence of CD8+ T lymphocytes was reported, compared with the fluid obtained from the control group lambs [31]. Bovine CD8 T cells target the M2, F, N, and G proteins of bRSV [33,34]. In mice and humans, the reactions of CD4 and CD8 T cells are directed to epitopes 
in most RSV proteins, including N, M, NS2, M2-1, F, and G [9]. As evidence of their importance during infection, depletion of CD8 T cells from bovine RSV-infected calves leads to more serious diseases and causes increased viral shedding compared with control animals [60]. In the present study, the presence of CD8 T lymphocytes was detected in five cases (see Table 3 and Figure 6).

In our research, the number of $\mathrm{CD} 8+$ cases was found to be less than that of CD3+ cases. This may be due to the duration of the infection. In the study of Sow FB [7], in the lungs of lambs infected with human RSV A2 strain, RSV titers were lower on day 3 after infection, markedly increased on day 6, and decreased to basal levels on day 14. In the same study, in the evaluation performed by flow cytometry, a significant increase in CD1, CD4, and CD8 cell levels was detected at 6 days, and the macrophage infiltration peak was observed on day 6. In another study [61], cytotoxic T cell activity was reported to peak at 7-10 days after infection. Although RSV induces a cytotoxic $T$ cell response, this has been reported to be weak and transient $[61,62]$. In addition, large populations of memory $\mathrm{T}$ cells remain in the airways and lung parenchyma, gradually decreasing within a few months and then stabilizing at a low level [63]. In our study, the duration of infection could not be determined because the animals from which the samples were taken were naturally infected. Therefore, we think that the lymphocytes involved in the infection may vary accordingly. However, the detection of CD3+ T lymphocytes in most RSV-positive cases (77\%) clearly demonstrates that these cells play an important role in RSV infection.

Neutrophils produce a wide range of inflammatory products, including oxidants and proteolytic enzymes, and they play a role in the development of acute and chronic lung disease $[64,65]$. RSV immune complexes have been shown to stimulate neutrophil activity [66]. RSV infection stimulates human alveolar macrophages [67] and airway epithelial cells [68] to produce large amounts of IL-8. In turn, IL-8 is known to be a potent chemotactic and activator for neutrophils [69], and this cytokine is likely to play a central role in the neutrophil flow seen in RSV infections. In the present study, H\&E examination of the lung sections of RSV-positive animals showed that neutrophils were predominantly present in the inflammation cells. Although the level of neutrophils has been reported to increase due to the presence of bacterial agents, such as Mannheimia and Mycoplasma [25], in light of the above literature data, it may be thought that neutrophils play an important role in the immune response to RSV.

The macroscopic and histopathological findings of this study were consistent with the studies previously reported in sheep [22,70], goats [4], and cattle [25,42]. Most of the macroscopic lesions were lobular and consisted of consolidated red or greyish-white lung tissue, especially in the cranial lobes of the lung. Demarcation lines were prominent between the pneumonic lobes and unaffected areas [22,42]. However, as previously noted in studies on natural RSV infections, it is unclear to what degree the described lesions result from the additional or synergistic effect of combined pathogens [22,25]. This is because the presence of other pulmonary pathogens, such as adenovirus, $P$. haemolytica, P. multocida, and Mycoplasma spp., has been reported to cause simultaneous 
infections with RSV. In addition, RSV has been reported to increase susceptibility to secondary bacterial infections, such as P. multocida and M. haemolytica [25].

The findings of our study contribute to the understanding of RSV pathogenesis and may simplify the development of new approaches for prevention and treatment. The increase in the immune expression of iNOS and CD3 in most of the RSV-positive cases showed that they play an important role in the immune response. However, the effects of the presence of other possible pathogens on their expression could not be ignored, since cases of a natural infection were examined.

\section{Acknowledgments}

Authors want to thank Van Yuzuncu Yil University Scientific Research Projects Foundation (Project number; TYL-2019-8309). This study was prepared from Cehun Aydemir's master thesis.

\section{Authors' contributions}

TY and CA contributed to study concept and design, analysis and interpretation of data, critical revision of the manuscript, final approval of the version to be published.

\section{Declaration of conflicting interests:}

The author(s) declared no potential conflicts of interest with respect to the research, authorship, and/or publication of this article.

\section{REFERENCES}

1. Pulat H. Koyunlarda respiratory syncytial virüs izolasyonu ve seroepidemiyolojisi. Ankara university, Institute of Health Sciences, PhD thesis. Ankara. 1992.

2. Dungworth DL: The respiratory system. In: Pathology of domestic Animals. New York, Academic Press; 1993; 539-699.

3. Eleraky NZ, Kania SA, Potgieter LN: The Ovine Respiratory Syncytial Virus F Gene Sequence and its Diagnostic Application. J Vet Diagn Invest 2001; 13:455-61.

4. Ceribasi S, Ozkaraca M, Ozer H, Ceribasi AO: Diagnosing Respiratory Syncytial Virus using Immunofluorescence and Immunohistochemistry Methods in Caprine Lungs with Bronchopneumonia. Revue Méd Vét 2013; 164:120-24.

5. Gürçay M, Bolat Y: Serological Survey Of Respiratory Synctial Virus RSV Infections Of Sheep In Elazig And It s Vicinity. FU Sag Bil Derg 1996; 10(2), 289-93.

6. Sacco RE, McGill JL, Pillatzki AE, Palmer MV, Ackermann MR: Respiratory syncytial virus infection in cattle. Vet Pathol 2014; 51:427-36.

7. Sow FB, Gallup JM, Olivier A, Krishnan S, Patera AC, Suzich J, Ackermann MR: Respiratory syncytial virus is associated with an inflammatory response in lungs and architectural remodeling of lung-draining lymph nodes of newborn lambs. Am J Physiol Lung Cell Mol Physiol 2011; 300:L12-L24. 
8. McInnes E, Sopp P, Howard CJ, Taylor G: Phenotypic analysis of local cellular responses in calves infected with bovine respiratory syncytial virus. Immunology 1999; 96:396-403.

9. Meyer G, Deplanche M, Schelcher F: Human and bovine respiratory syncytial virus vaccine research and development. Comp Immunol Microbiol Infect Dis 2008, 31:191-225.

10. Sözmen M, Tunca R, Beytut E, Gürbüz A: CD3 and Lambda Light Chain Immunglobulin Expressions in the Aborted Sheep Fetuses Naturally Infected with Brucella melitensis. Kafkas Univ Vet Fak Derg 2010; 16:353-63

11. Johnson JE, Gonzales RA, Olson SJ, Wright PF, Graham BS: The histopathology of fatal untreated human respiratory syncytial virus infection. Mod Pathol 2007; 20:108-19.

12. Lowenstein CJ, Dinerman JL, Snyder SH: Nitric oxide: a physiologic messenger. Ann Intern Med 1994; 120:227-37.

13. Moncada S, Palmer RM, Higgs E A: Nitric oxide: physiology, pathophysiology, and pharmacology. Pharmacol Rev 1991; 43:109-42.

14. Barnes PJ, Liew FY: Nitric oxide and asthmatic inflammation. Immunol Today 1995; 16:128-30.

15. Akaike T, Noguchi Y, Ijiri S, Setoguchi K, Suga M, Zheng YM, Dietzschold B, Maeda H: Pathogenesis of influenza virus-induced pneumonia: involvement of both nitric oxide and oxygen radicals. Proc Natl Acad Sci 1996; 93:2448-53.

16. Mannick JB: The antiviral role of nitric oxide. Res Immunol 1995; 146:693-7.

17. Reiss CS, Komatsu T: Does nitric oxide play a critical role in viral infections? J Virol. 1998; 72:4547-51.

18. Komatsu T, Bi Z, Reiss CS: Interferon-gamma induced type I nitric oxide synthase activity inhibits viral replication in neurons. J Neuroimmunol 1996; 68:101-8.

19. Tucker PC, Griffin DE, Choi S, Bui N, Wesselingh S: Inhibition of nitric oxide synthesis increases mortality in Sindbis virus encephalitis. J Virol 1996; 70:3972-7.

20. Billiar TR, Curran RD, Harbrecht BG, Stadler J, Williams DL, Ochoa JB, Di Silvio Simmons MRL, Murray SA: Association between synthesis and release of cGMP and nitric oxide biosynthesis by hepatocytes. Am J Physiol 1992; 262:1077-82.

21. Lacza Z, Snipes JA, Zhang J, Horváth EM, Figueroa JP, Szabó C, Busija DW: Mitochondrial nitric oxide synthase is not eNOS, nNOS or iNOS. Free Radic Biol Med 2003; 35:1217-28.

22. Gülbahar Y, Çabalar M, Ertürk A: Detection by immunoperoxidase technique of parainfluenza type-3 virus and respiratory syncytial virus antigens in naturally occurring pneumonia in lambs. Van Vet J 2002; 13:74-7.

23. Bryson DG, Cush PF, McNulty MS, Platten M, Allan G: An immunoperoxidase method of detecting respiratory syncytial virus antigens in paraffin sections of pneumonic bovine lung. Am J Vet Res 1988; 49:1121-16.

24. Ciszewski DK, Baker JC, Slocombe RF, Reindel JF, Haines DM, Clark EG: Experimental reproduction of respiratory tract disease with bovine respiratory syncytial virus. Vet Microbiol 1991; 28:39-60.

25. Yaman T, Büyükbayram H, Özyıldız Z, Terzi F, Uyar A, Keles ÖF, Özsoy ŞY, Yener Z: Detection of bovine respiratory syncytial virus, Pasteurella multocida, and Mannheimia haemolytica by immunohistochemical method in naturally-infected cattle. J Vet Res 2018; 62:439-45.

26. Jarikre TA, Emikpe BO: First report of immunohistochemical detection of Peste des petit ruminants, parainfluenza 3 and respiratory syncytial viral antigens in lungs of Nigerian goats. J Immunoass Immunoch 2017; 38:555-68. 
27. Prince GA, Porter DD: The pathogenesis of respiratory syncytial virus infection in infant ferrets. Am J Pathol 1976; 82:339-52.

28. Belshe RB, Richardson LS, London WT, Sly DL, Lorfeld JH, Camargo E, Prevar DA, Chanock RM: Experimental respiratory syncytial virus infection of four species of primates. J Med Virol 1977; 1:157-62.

29. Collier AM, Clyde WA: Model systems for studying the pathogenesis of infections causing bronchiolitis in man. Pediatr Res 1977; 11:243-6.

30. Richardson LS, Belshe RB, Sly DL, London WT, Prevar DA, Camargo E, Chanock RM: Experimental respiratory syncytial virus pneumonia in cebus monkeys. J Med Virol 1978; 2:45-9.

31. Sharma R, Woldehiwet Z: Pathogenesis of bovine respiratory syncytial virus in experimentally infected lambs. Vet Microbiol 1990; 23:267-72.

32. Sharma R, Woldehiwet Z, Spiller DG, Warenius HM: Lymphocyte subpopulations in peripheral blood of lambs experimentally infected with bovine respiratory syncytial virus. Vet Immunol Immunopathol 1990; 24:383-91.

33. Gaddum RM, Cook RS, Furze JM, Ellis SA, Taylor G: Recognition of bovine respiratory syncytial virus proteins by bovine CD8 T lymphocytes. Immunology 2003; 108:220-9.

34. Taylor G, Thomas LH, Furze JM, Cook RS, Wyld SG, Lerch R, Hardy R, Wertz GW: Recombinant vaccinia viruses expressing the $\mathrm{F}, \mathrm{G}$ or $\mathrm{N}$, but not the $\mathrm{M} 2$, protein of bovine respiratory syncytial virus (BRSV) induce resistance to BRSV challenge in the calf and protect against the development of pneumonic lesions. J Gen Virol 1997; 78:3195-206.

35. Graham Ss Bunton LA, Wright PF, Karzon DT: Role of T lymphocyte subsets in the pathogenesis of primary infection and rechallenge with respiratory syncytial virus in mice. J Clin Invest 1991; 88:1026-33.

36. Belknap EB, Ciszewski DK, Baker JC: Experimental respiratory syncytial virus infection in calves and lambs. J Vet Diagn Invest 1995; 7:285-98.

37. Baker JC: Bovine respiratory syncytial virus: pathogenesis, clinical signs, diagnosis, treatment, and prevention. Compend Food Anim 1986; 8:31-8.

38. Haines DM, Clark EG, Chelack BJ: The detection of bovine respiratory syncytial virus in formalin fixed bovine lung with commercially available monoclonal antibodies and avidin biotin complex immunohistochemistry. Can J Vet Res 1989; 53:366-8.

39. Jericho KWF: Histological Changes in the Respiratory Tract of Calves Exposed to Aerosols of Bovine Herpesvirus 1 and Pasteurella haemolytica. J Comp Pathol 1983; 93:73-82.

40. Ceribasi AO. Ozkaraca M. Ceribasi S. Ozer H: Histopathologic, Immunoperoxidase and Immunofluorescent Examinations on Natural Cattle Pneumonia Originated from Parainfluenza Type 3, Respiratory Syncytial Virus, Adenovirus Type 3 and Herpesvirus Type 1. Revue Med Vet 2014; 165:201-12.

41. Evermann JF, Liggitt HD, Parish SM, Ward AC, LeaMaster BR: Properties of a respiratory syncytial virus isolated from a sheep with rhinitis. Am J Vet Res 1985; 46:947-51.

42. Ozyildiz Z, Ozmen O, Serpin N, Dolu H, Kutlu T, Ozsoy SY: Investigation of mannosebinding lectin, surfactant protein $\mathrm{B}$ and heat shock protein expression in bovine respiratory syncytial virus infection. Rev Med Vet 2019; 170:2-8.

43. Almeida RS, Domingues HG, Coswig LT, d'Arce RCF, de Carvalho RF, Arns CW: Detection of bovine respiratory syncytial virus in experimentally infected balb/c mice. Vet Res 2004; 35:189-97. 
44. Adler H, Beland JL, Del-Pan NC, Kobzik L, Brewer JP, Martin TR, Rimm IJ: Suppression of herpes simplex virus type 1 (HSV-1)-induced pneumonia in mice by inhibition of inducible nitric oxide synthase (iNOS, NOS2). J Exp Med 1997; 185:1533-40.

45. Sanders SP, Siekierski ES, Porter JD, Richards SM, Proud D: Nitricoxide inhibits rhinovirusinduced cytokine production and viral replication in a human respiratory epithelial cell line. J Virol 1998; 72:934-42.

46. Zsengeller ZK, Ross GF, Trapnell BC, Szabo C, Whitsett JA: Adenovirus infection increases iNOS and peroxynitrite production in the lung. Am J Physiol Lung Cell Mol Physiol 2001; 280:503-11.

47. Sanders SP, Siekierski ES, Richards SM, Porter JD, Imani F, Proud D: Rhinovirus infection induces expression of type 2 nitric oxide synthase in human respiratory epithelial cells in vitro and in vivo. J Allergy Clin Immunol 2001; 107:235-43.

48. Kao YJ, Piedra PA, Larsen GL, Colasurdo GN: Induction and regulation of nitric oxide synthase in airway epithelial cells by respiratory syncytial virus. Am J Respir Crit Care Med 2001; 163:532-9.

49. Stark JM, Khan AM, Chiappetta CL, Xue H, Alcorn JL, Colasurdo GN: Immune and functional role of nitric oxide in a mouse model of respiratory syncytial virus infection. J Infect Dis 2005; 19:387-95.

50. Noah TL, Becker S: Respiratory syncytial virus-induced cytokine production by a human bronchial epithelial cell line. Am J Physiol 1993; 265:472-8.

51. Stark JM: The induction of chemokines by viruses in allergic states. In: Chemokines in allergic disease. New York: Marcel Dekker; 2000, 263-87.

52. Chini BA, Fiedler MA, Milligan L, Hopkins T, Stark JM: Essentialroles of NF-kB and C/ EBP in the regulation of intercellular adhesion molecule-1 after respiratory syncytial virus infection of human respiratory epithelial cell cultures. J Virol 1998; 72:1623-6.

53. O'Donnell DR, Milligan L, Stark JM: Induction of CD95 (Fas) and apoptosis in respiratory epithelial cell cultures following respiratory syncytial virus infection. Virology 1999; 257:198-207

54. Nathan C: Nitric oxide as a secretory product of mammalian cells. FASEB J 1992; 6:305164.

55. Xie Q, Nathan C: The high-output nitric oxide pathway: role and regulation. J Leukoc Biol 1994; 56:576-82.

56. Ricciardolo FL: Multiple roles of nitric oxide in the airways. Thorax 2003; 58:175-82.

57. Choi HS, Rai PR, Chu HW, Cool C, Chan ED: Analysis of nitric oxide synthase and nitrotyrosine expression in human pulmonary tuberculosis. Am J Respir Crit Care Med 2002; 166:178-86.

58. Eynott PR, Groneberg DA, Caramori G, Adcock IM, Donnelly LE, Kharitonov S, Barnes PL, Chung KF: Role of nitric oxide in allergic inflammation and bronchial hyperresponsiveness. Eur J Pharmacol 2002; 452:123-33.

59. Nevin BJ, Broadley KJ: Nitric oxide in respiratory diseases. Pharmacol Ther 2002; 95:25993.

60. Thomas LH, Cook RS, Howard CJ, Gaddum RM, Taylor G: Influence of selective T-lymphocyte depletion on the lung pathology of gnotobiotic calves and the distribution of different T-lymphocyte subsets following challenge with bovine respiratory syncytial virus. Res Vet Sci 1996; 61:38-44. 
61. Woolums AR, Gunther RA, McArthur-Vaughan K, Anderson ML, Omlor A, Boyle G A, Friebertshauser KE, McInturff PS, Gershwin LJ: Cytotoxic T lymphocyte activity and cytokine expression in calves vaccinated with formalin-inactivated bovine respiratory syncytial virus prior to challenge. Comp Immunol Microbiol Infect Dis 2004; 27:57-74.

62. Gaddum RM, Cook RS, Thomas LH, Taylor G: Primary cytotoxic T-cell responses to bovine respiratory syncytial virus in calves. Immunology 1996; 88:421-7.

63. Moldoveanu B, Otmishi P, Jani P, Walker J, Sarmiento X, Guardiola J, Saad M, Yu J: Inflammatory mechanisms in the lung. J Inflamm Res 2009; 2 (1):1-11

64. Sibille Y, Reynolds HY: State of the art. Macrophages and polymorphonuclear neutrophils in lung defense and injury. Am Rev Respir Dis1990; 141:471-501.

65. Donnelly SC, Haslett C: Cellular mechanisms of acute lung injury: implications for future treatment in the adult respiratory distress syndrome. Thorax 1992; 47:260-3.

66. Faden H, Kaul TN, Ogra PL: Activation of oxidative and arachidonic acid metabolism in neutrophils by respiratory syncytial virus antibody complexes: possible role in disease. Infect Dis 1983; 148:110-6.

67. Becker S, Koren HS, Henke DC: Interleukin-8 expression in normal nasal epithelium and its modulation by infection with respiratory syncytial virus and cytokines tumour necrosis factor, interleukin-I and interleukin-6. Am J Respir Cell Mol Biol 1993; 8:20-7.

68. Becker S, Quay J, Soukup J: Cytokine (tumour necrosis factor, IL-6 and I1-8) production by respiratory syncytial virus-infected human alveolar macrophages. J Immunol 1991; 12 : 4307-12.

69. Leonard EJ, Yoshimura T: Neutrophil attractant/activation protein-1 (NAP-I [interleukin-8]). Am. J. Respir. Cell Mol Biol 1990;, 2:479-86.

70. Haziroğlu R, Diker KS, Turkarslan J, Gulbahar MY: Detection of Mycoplasma ovipneumoniae and Pasteurella haemolytica antigens by an immunoperoxidase technique in pneumonic ovine lungs. Vet Pathol 1996;, 33:74-6.

\title{
INFEKCIJA RESPIRATORNIM SINCICIJALNIM VIRUSOM INDUKUJE EKSPRESIJU INDUSIBILNE AZOT OKSID SINTAZE, CD3, I CD8 KOD PNEUMONIJE JAGNJADI
}

\author{
Turan YAMAN, Ceyhun AYDEMIR
}

Respiratorni sincicijalni virus (RSV) je RNK virus koji pripada rodu Pneumovirus iz porodice Paramyxoviridae. Cilj ove studije bio je da se proceni ekspresija inducibilne sintetaze azotnog oksida (iNOS), CD3 (pan T ćelija) i CD8 (citotoksičnih T ćelija) u plućima jagnjadi prirodno inficirane RSV-om primenom imunohistohemije (IHC). U tu svrhu uzeto je 100 uzoraka pluća i 10 kontrolnih uzoraka plućnog tkiva jagnjadi zaklanih u klanici, nakon makroskopskog pregleda. Za IHC bojenje korišćena je metoda streptavidin-peroksidaze (ABC) koja je otkrila pozitivnost RSV u 18 od 100 pregledanih pneumoničnih pluća $(18 \%)$. 
Ovi pozitivni slučajevi su zatim imunohistohemijski obrađeni za iNOS, CD3 i CD8 i upoređeni sa kontrolama. U svim ovim slučajevima otkriven je porast ekspresije iNOS (100\%), veći broj CD3 + T limfocita otkriven je u 14 (78\%) slučajeva, dok su CD8 + T limfociti dokayani samo u pet (28\%) slučajeva. S obzirom na povećanje iNOS imunoekspresije u svim RSV-pozitivnim slučajevima i povećanje broja CD3 + T limfocita u većini slučajeva, zaključeno je da iNOS i CD3 + T limfociti igraju važnu ulogu u imunskom odgovoru kod RSV pneumonije jagnjadi koja se prirodno javlja. Ovom studijom je prvi put procenjena uloga pomenutih markera kod jagnjadi prirodno zaraženih RSV-om. 